\title{
Vertical Profile of Leaf Nitrogen Distribution at Different Densities of Plant And Different Levels of N Fertilizer on Corn Hybrids Canopy
}

\author{
Soraya Ghasemi ${ }^{1}$, Ali Reza Kochaki ${ }^{1}$, Mehdi Nassiri Mahalati ${ }^{1} \&$ Rajab Choukan ${ }^{2}$ \\ ${ }^{1}$ Faculty of agronomy, Ferdowsi University of Mashhad, Mashhad, Iran \\ ${ }^{2}$ Seed and Plant Improvement Institute, Iran \\ Correspondence: Ali Reza Kochaki, Faculty of agronomy, Ferdowsi University of Mashhad, Mashhad, Iran. \\ E-mail: akooch@um.ac.ir
}

Received: June 17, 2016

Accepted: July 8, 2016

Online Published: July20, 2016

doi:10.5539/mas.v10n12p57

URL: http://dx.doi.org/10.5539/mas.v10n12p57

\begin{abstract}
In this study, the distribution of leaf nitrogen of two corn hybrids during the growing season, in response to the density and $\mathrm{N}$ supply were studied. There were two corn hybrids (S.C. 704 and maxima (MV 524)) under three levels of nitrogen: Recommended (300 kg N/ha); RDN plus $25 \%$ (375 kg N/ha); RDN plus $50 \%(450 \mathrm{~kg} \mathrm{~N} / \mathrm{ha})$ and were three levels of population. Recommended (RDN) (7 plants $\left.\mathrm{m}^{-2}\right)$; RDN plus $10 \%(7.7$ plants $\mathrm{m}-2)$; RDN plus $20 \%\left(8.4\right.$ plants $\left.\mathrm{m}^{-2}\right)$.Regular samplings were made from 40 days after sowing until crop maturity. Every 2 weeks, a $1 \mathrm{~m} 2$ sample of the canopy was cut in four successive vertical layers of equal thickness. Leaf area and $\mathrm{N}$ concentration (\%) in each layer were measured. The vertical $\mathrm{N}$ gradient became more marked with ongoing vegetative development. The whole canopy photosynthetic benefit that would accrue from maintaining the $\mathrm{N}$ gradient is likely to be accentuated. The rate of decline in leaf $\mathrm{N}$ concentration in a layer was not related to either the initial concentration in the leaves within the layer.
\end{abstract}

Keywords: maize, specific nitrogen of leaf, nitrogen distribution, density

\section{Introduction}

Nitrogen is the most important element required for plant growth and development. It is a key component in many biological compounds and plays an important role in the biosynthetic activity and crop yield capacity (Cathcart \& Swanton, 2003). Variation in nitrogen availability, can affect plant development and grain production in maize. In recent years, in a practical framework, two mechanisms of plant reaction which lead to a lack of nitrogen were investigated (Vos et al., 2005; Lemaier et al., 2007; Lemaier \& Gastal, 2009). The reactions were associated with reductions in the following cases: 1) to reduce the absorption of resources (in this case, the lack of nitrogen through leaf growth and reduction of the impact on leaf area reduces to absorb resources such as the light and as well as limited sources (source)) Or 2) the reduction of the efficiency of resource consumption (e.g., reduction in efficiency of light consumption) (Lemaierand et al., 2008). The identified species as the second type of nitrogen reaction, such as corn and tall fescue (Festucaar undinacea Schreb.), By diluting nitrogen stored in the canopy, as well as photosynthetically active radiation conversion to biomass, the mount of reduction of leaf area under drought stress minimize nitrogen (Muchow \& Davis, 1988; Vos et al., 2005; Lamaier et al., 2008). The second type of species (reduction in resource use efficiency) can by the stabilization of the concentration of nitrogen of leaf (nitrogen) and maintain of the photosynthetic capacity, a decrease in leaf growth, regulates the effects of nitrogen deficiency (Lemaieret et al. 1992; Vos \& Van der Putten, 1998; Lemaier et al., 2008). Determining the optimum density for proper use of inputs such as land, water, light and nutrients is essential to improve the quantity and quality of the product and plays an important role in closing to the potential of crop production. Since the important characteristics of improved varieties of maize, is lack of tillering so the number of plants in level unit is important. Optimum density to achieve more performance according to genotype, climatic conditions, soil fertility and plant model could be modified (De André, 2008). If the necessary inputs of growth exist in an environment and adequate time, the production capacity can be determined by appropriate distribution of plants in the vegetation (Ciyampitti \& Vyn, 2012).the optimal density of maize according to varieties (early, middle and late maturing) geographical locations are different.so late maturing hybrids with increasing number and steady of leaf area and absorbing more radiation produce the maximum of dry matter. The maximum of dry matter is compensated by the high density of early maturing hybrids (Farnham, 
2001). Leaf $\mathrm{N}$ allocation can be studied in relation to the resource capture component by examining the specific leaf N (SLN, leaf N content to LAI). The SLN can be further dissected into two components, i) the leaf mass per unit of LAI, so called specific leaf weight (SLW), and ii) the leaf $\mathrm{N}$ per unit of leaf mass, leaf $\% \mathrm{~N}\left(\mathrm{~g} \mathrm{~N} \mathrm{~g}^{-1}\right.$ dry matter $[\mathrm{DM}])$. Variability in the SLN was documented during vegetative development at both canopy and at leaflaminae scales (Drouet \& Bonhomme, 1999, 2004). At canopy level, critical SLN values have been documented for leaf expansion $\left(1.0 \mathrm{~g} \mathrm{~m}^{-2}\right.$ ) (Muchow \& Davis, 1988; Muchow \& Sinclair, 1994). Many studies show that plant nitrogen concentration decreases during the growth cycle in dense canopies. This is the result of two processes: (i) self-shading of leaves that induces a non-uniform leaf $\mathrm{N}$ content from the top canopy layers with high $\mathrm{N}$ concentration to the shaded layers with low N concentration (Field, 1983; Hirose \& Werger, 1987; Pons \& Pearcy, 1994; Sinclair \& Horie, 1989) and (ii) an increase in the proportion of plant structural and storage tissues with a lower nitrogen concentration, even when crops grow with non-limiting $\mathrm{N}$ supply (Caloin \& Yu, 1984; Charles-Edwards et al., 1987).

The aim of this study is to determine firstly to determine whether a clear $\mathrm{N}$ gradient existed in corn canopy? And if so, whether the gradient how is in the late and medium maturing hybrids of corn? Secondly, whether the gradient could be related to plant populations? Thirdly, what effect does the $\mathrm{N}$ fertilizer levels have on vertical profiles of corn hybrid nitrogen?

\section{Material and Methods}

The field experiment was conducted at Ilam agricultural research center, Dehloran (situated at $33^{\circ}-51^{\prime} \mathrm{N}$ latitude and $46^{\circ}-16^{\prime} \mathrm{E}$ longitude at a mean height of $180 \mathrm{~m}$ above sea level), Iran. Crops were sown with a commercial row crop planter with a $0.75 \mathrm{~m}$ row spacing and were established and grown with full irrigation and using high input management and insect control. Seeds of hybrids were obtained from department of seed and Plant Breeding during two seasons, July till November $(2013 ; 2014$, respectively). The mean daily temperature of June till September ranges between $32^{\circ} \mathrm{C}$ and $40^{\circ} \mathrm{C}$ while during October it is between $25^{\circ} \mathrm{C}$ and $32^{\circ} \mathrm{C}$.

The treatments were two corn hybrids of single cross 704 (SC 704) and Maxima (MV 524) in the main plots and 9 sub-plots consists of 3 levels of $\mathrm{N}$ fertilizer Recommended (300 kg N/ha); RDN plus $25 \%$ ( $375 \mathrm{~kg} \mathrm{~N} / \mathrm{ha}$ ); RDN plus $50 \%$ (450 kg N/ha) and three levels of population. Recommended (RDN) (7 plants $\mathrm{m}^{-2}$ ); RDN plus $10 \%$ $\left(7.7\right.$ plants $\left.\mathrm{m}^{-2}\right)$; RDN plus $20 \%\left(8.4\right.$ plants $\left.\mathrm{m}^{-2}\right)$. All the operations except nitrogen for all treatments were done equally and simultaneously.

\section{Measurements}

The mount of dry matter, leaf area, leaf nitrogen content, and specific leaf weight were measured In each plot a 1 $\mathrm{m} 2$ area of the crop canopy was cut in four successive layers of equal vertical thickness (layer 1 being the top, layer 4 the bottom).The leaf area (and hence leaf area index, L) in each layer was then measured with a calibrated planimeter. Leaf samples were dried in a forced draught oven at $70{ }^{\circ} \mathrm{C}$ and weighed. The material was then ground and analysed for $\mathrm{N}$ concentration on a mass basis (LNC, $\mathrm{gNg}^{-1} \mathrm{~d}$. wt) using a near infrared refractometer (PertenInframatic 8100, Hamburg, Germany) calibrated against the Kjeldahl method. In our experiment specific weight of leaf was calculated using the formula 1.

$$
\mathrm{SLW}=\mathrm{LDM} / \mathrm{LA}
$$

Where LDM is leaf dry matter, LA, leaf area and SLW is specific leaf weight $\left(\mathrm{g} / \mathrm{m}^{2}\right.$ leaf $)$. Then the dried samples by micro-Kjeldahl method, and in leaf nitrogen content was measured and with the amount of leaf nitrogen content and specific leaf weight, using the formula (2), specific leaf nitrogen was calculated for each layer. Where, $\mathrm{SLN}$ is specific leaf nitrogen $\left(\mathrm{g} \mathrm{N} / \mathrm{m}^{2}{ }_{\text {leaf }}\right), \mathrm{LNC}$ is percentage of leaf nitrogen $\left(\mathrm{gN} / \mathrm{g}_{\text {leaf }}\right)$

$$
\mathrm{SLN}=\mathrm{LNC} \times \mathrm{SLW}
$$

\section{Results and Discussion}

\subsection{Whole Canopy Nitrogen Dynamics}

Variance analysis showed that various hybridsaccording to the amount of nitrogen per unit of leaf areahad not significantly different.Figure 1presents the difference between different densities in terms of nitrogen level per unit leaf area. Based on this process, nitrogen in leaves increased at the beginning of growth and then decreased. The increase continued until 55 days after planting. Increased nitrogen per unit leaf area in early growth could be due to rapid growth and high rates of net assimilation rate because of the net assimilation rate (NAR). The main reason for the decline in the final stages of growth is that in the dense and non-dense canopies the concentration of nitrogen is reduced during the growth cycle in the plant. 


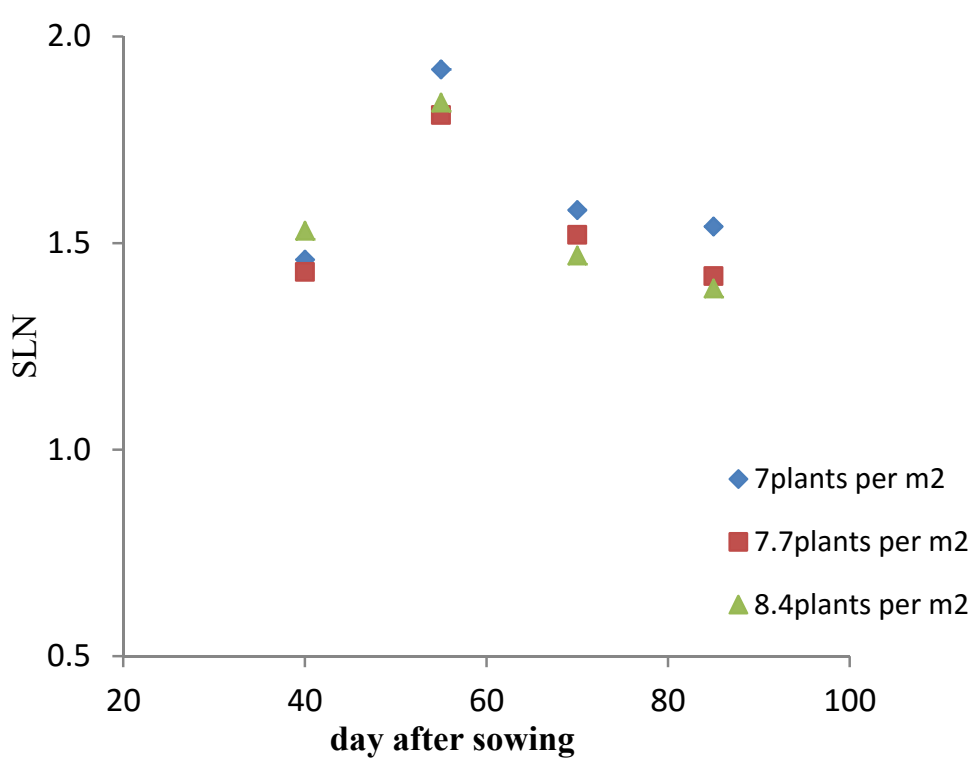

Figure 1. Whole canopy dynamics of leaf nitrogen per unit leaf area (SLN) in different plant density

The reaction of nitrogenper unit of leaf area (SLN) to the different levels of fertilizer and density was quite different (Figure 2 compared to Figure 1). In $375 \mathrm{~kg} / \mathrm{ha} \mathrm{N}$ fertilizer, leaf $\mathrm{N}$ concentration, on a leaf area (SLN), declined with crop age; at maturity, it was about half the value measured 60 DAS (Figure 2). In 300 and 450 $\mathrm{kg} / \mathrm{ha} \mathrm{N}$ fertilizer, SLN showed a biphasic pattern, declining initially, then increasing (Figure 2). These two phases were more marked in the RDN than in the fertilized crop; the end of the decline phase occurred earlier and the increase was sharper in the $\mathrm{RDN}+50 \%(450 \mathrm{~kg} / \mathrm{ha})$. The biphasic pattern was not seen in $\mathrm{RDN}+25 \%$. The main reason for the decline in the final stages of development can be said that in the dense and non-dense canopy during the growing cycle, the nitrogen concentration in the plant would be reduced.

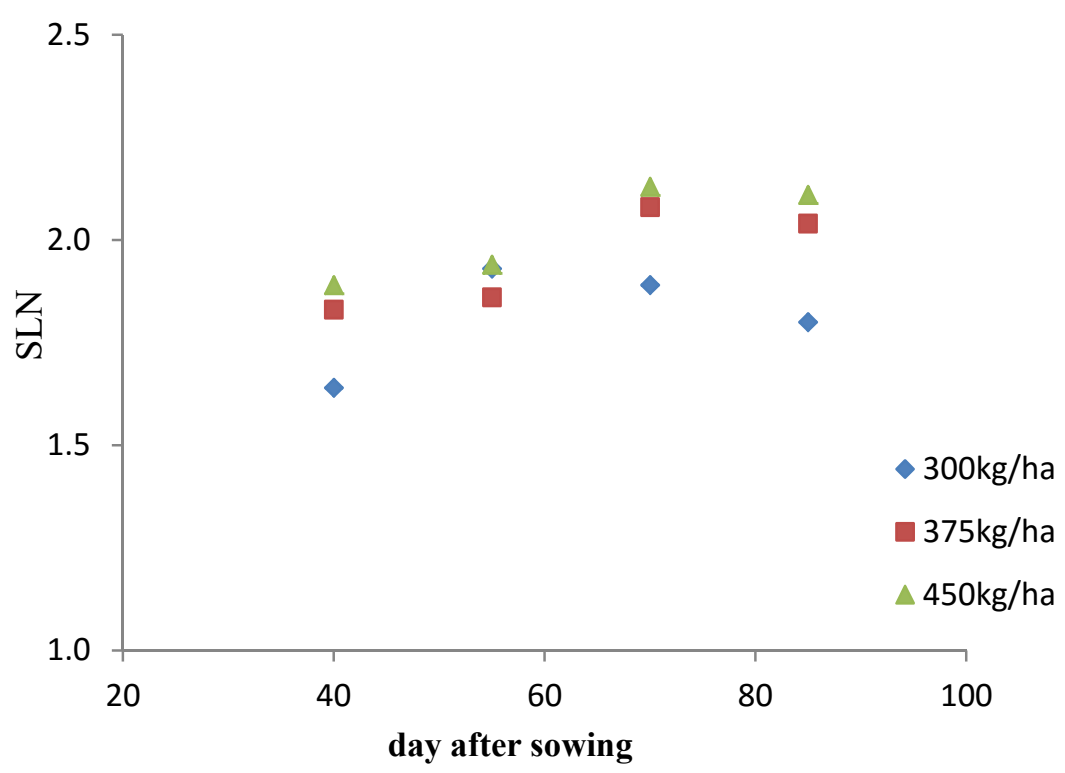

Figure 2. The trend of nitrogen changes per unit of leaf area at different levels of $\mathrm{N}$ fertilizer

It seems that the reduction in the nitrogen content of leaves to support the filling of grains is certainly essential because in the final stages of development, the actual amount of absorbed nitrogen was possible that to provide the needed nitrogen to make proteins, hadnot enough seed. orderly, these reductions cause the loss of index and leaf level of productsand to fade leaf (the Sinkelar \& De-Witt, 1975) When the supply of nitrogen, is not enough 
for the potential need of the plant, products cannot (1) produce a large number of leaves in per plant (2) gain the potential area in each leaf (3) sustain the needed SLN levels of unlimited growth (Vos \& Van der Putten, 1998). When nitrogen cannot answer to the current needs product can reduce SLN of the leaf surface, while it maintains the surface growth of leaf (strategy I) Or can be maintained by reducing the leaf level and SLN through restricting the development of young leaves, and to reduce the need to nitrogen in leaves (Strategy 2) (Vos \& Van der Putten, 1998; Hammer et al., 2000) or by the old leaves and nitrogen remobilization (Hammer et al., 2000) achievesthe own goal, or employsa combination of these strategies.

Table 1. Hybrid interaction and density of leaf nitrogen per unitleaf area at different stages of growth

\begin{tabular}{cccccc}
\hline 85 & 70 & 55 & 40 days after sowing & Plant density & hybrid \\
\hline $1.55 \mathrm{a}$ & $1.95 \mathrm{a}$ & $1.31 \mathrm{~b}$ & $1.72 \mathrm{~b}$ & 7 plant per $\mathrm{m}^{2}$ & \\
$1.54 \mathrm{a}$ & $1.85 \mathrm{a}$ & $1.22 \mathrm{~b}$ & $1.65 \mathrm{~b}$ & 7.7 plant per m2 & S.C.704 \\
$1.54 \mathrm{a}$ & $1.80 \mathrm{~b}$ & $1.34 \mathrm{a}$ & $1.81 \mathrm{a}$ & 8.4 plant per m2 & \\
\hline $1.43 \mathrm{~b}$ & $1.77 \mathrm{~b}$ & $1.35 \mathrm{a}$ & $1.72 \mathrm{~b}$ & 7 plant per $\mathrm{m}^{2}$ & \\
$1.41 \mathrm{~b}$ & $1.81 \mathrm{a}$ & $1.38 \mathrm{a}$ & $1.89 \mathrm{a}$ & 7.7 plant per m2 & maxima \\
$1.52 \mathrm{a}$ & $1.89 \mathrm{a}$ & $1.36 \mathrm{a}$ & $1.84 \mathrm{a}$ & 8.4 plant per m2 & \\
\hline
\end{tabular}

Table 1 shows the interaction of hybrid and density of leaf nitrogen per unitleaf areaat different growth stages. In the shape, the hybrids advantage of single cross is addressed in the mount of $450 \mathrm{~kg} \mathrm{~N}$ fertilizer per hectare.

Table 2. Hybrid interaction and leaf nitrogen fertilizer at different stages of growthper unit leaf area

\begin{tabular}{cccccc}
\hline 85 & 70 & 55 & 40 days after sowing & $\mathrm{N}$ levels & hybrid \\
\hline $1.62 \mathrm{a}$ & $1.91 \mathrm{a}$ & $1.21 \mathrm{~b}$ & $1.54 \mathrm{c}$ & $300 \mathrm{~kg} / \mathrm{ha}$ & \\
$1.60 \mathrm{a}$ & $1.89 \mathrm{a}$ & $1.30 \mathrm{a}$ & $1.71 \mathrm{~b}$ & $375 \mathrm{~kg} / \mathrm{ha}$ & S.C.704 \\
$1.49 \mathrm{~b}$ & $1.79 \mathrm{~b}$ & $1.21 \mathrm{~b}$ & $1.74 \mathrm{~b}$ & $450 \mathrm{~kg} / \mathrm{ha}$ & \\
\hline $1.58 \mathrm{a}$ & $1.91 \mathrm{a}$ & $1.29 \mathrm{a}$ & $1.80 \mathrm{a}$ & $300 \mathrm{~kg} / \mathrm{ha}$ & \\
$1.55 \mathrm{a}$ & $1.88 \mathrm{a}$ & $1.31 \mathrm{a}$ & $1.82 \mathrm{a}$ & $375 \mathrm{~kg} / \mathrm{ha}$ & maxima \\
$1.43 \mathrm{~b}$ & $1.82 \mathrm{~b}$ & $1.30 \mathrm{a}$ & $1.74 \mathrm{~b}$ & $450 \mathrm{~kg} / \mathrm{ha}$ & \\
\hline
\end{tabular}

In general, in all treatments,a clear gradientof nitrogen was observed during the growing season (Figure 3-8). The gradient was just a phase that initially increased and then reduced the amount of nitrogen per unit leaf area (Figures 1-2 \& Tables 1-2).

\section{Nitrogen Dynamics in the Different Layers of Canopy}

Comparison of changes of nitrogen in the leaf surface shows a clear gradient of this trait in the canopy vertical profile (Figures 3-5). The gradient was observed at different stages of the growing season (Figure 1 \& Figure 2). In all treatments, the SLN in lower layers was less than the upper layers (Figures 3-8). In the all treatment, the mount of SLN in the first layer was about $1.5\left(\mathrm{gm}_{\text {Leaf }}^{-2}\right)$ at the beginning of growth was around $0.75\left(\mathrm{gm}^{-2}\right.$ Leaf $)$ to the last sampling. While the upper layers were steady and sometimes went up (Figure 3). Decline of nitrogen in per unit of leaf level with increasing canopy depth, was reflecting distribution and adaptation of nitrogen in the different levels of the canopy leaf. 


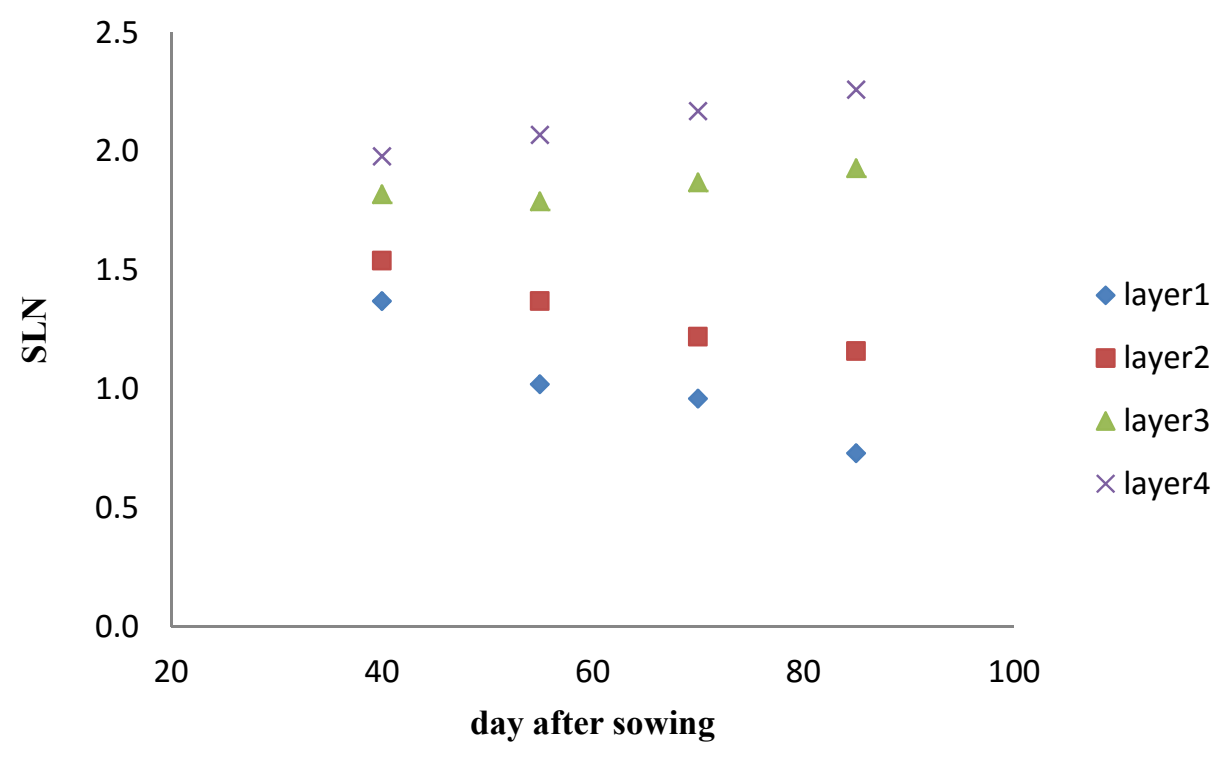

Figure 3. Dynamics of leaf $\mathrm{N}$ per unit leaf area (SLN) for the four canopy layers in $300 \mathrm{Kg} / \mathrm{ha}$ treatments

In each treatment, SLN gradients were consistently found over the duration of measurements (Figure 3-5). SLN was always lower in the lower layers of the canopies (Figure 3-5). RDN $+25 \%(375 \mathrm{~kg}$ ), the SLN of the top layer was relatively stable over time apart from a high value at 70 day after sowing (DAS). On the other hand, the lowest layer declined steadily from approx. $1.8 \mathrm{~g} \mathrm{~m} 2$ at 40 DAS to $0.8 \mathrm{~g} \mathrm{~m} 2$ at 85 DAS. In RDN and RDN + $50 \%$, the trend was for each layer to show an initial decline followed by an increase, reflecting the pattern of total canopy SLN (Figure 2). The duration of the decline was shortest in the top layer and the rate of increase was greater in the higher layers. As a consequence, in each of the three levels of Nitrogen, an increasing differential in SLN developed between the layers over time. This was most accentuated in the RDN (300 kg/ha) and least accentuated in $\mathrm{RDN}+25 \%$.

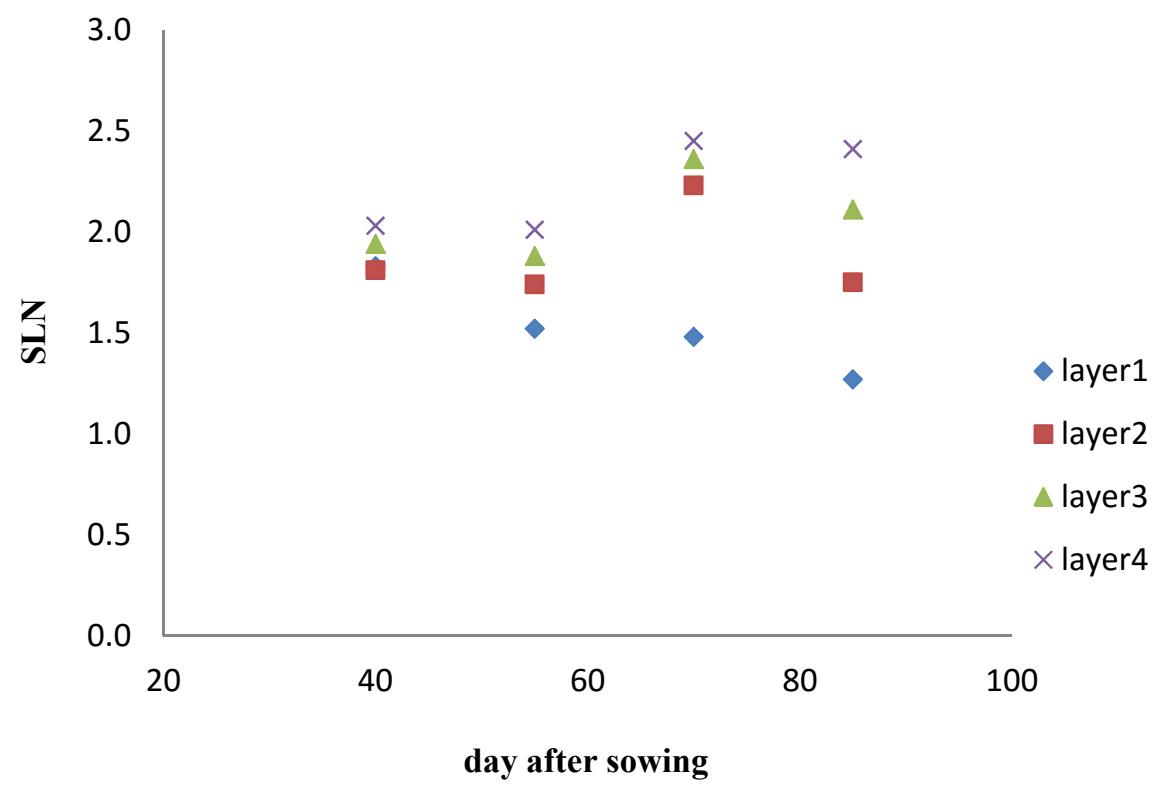

Figure 4. Dynamics of leaf $\mathrm{N}$ per unit leaf area (SLN) for the four canopy layers in $375 \mathrm{Kg} /$ ha treatments

In $\mathrm{RDN}+50 \%,(450 \mathrm{~kg} / \mathrm{ha})$ the reduction for upper canopy layers, with low slope, but the speed was increased (Figure 5). 


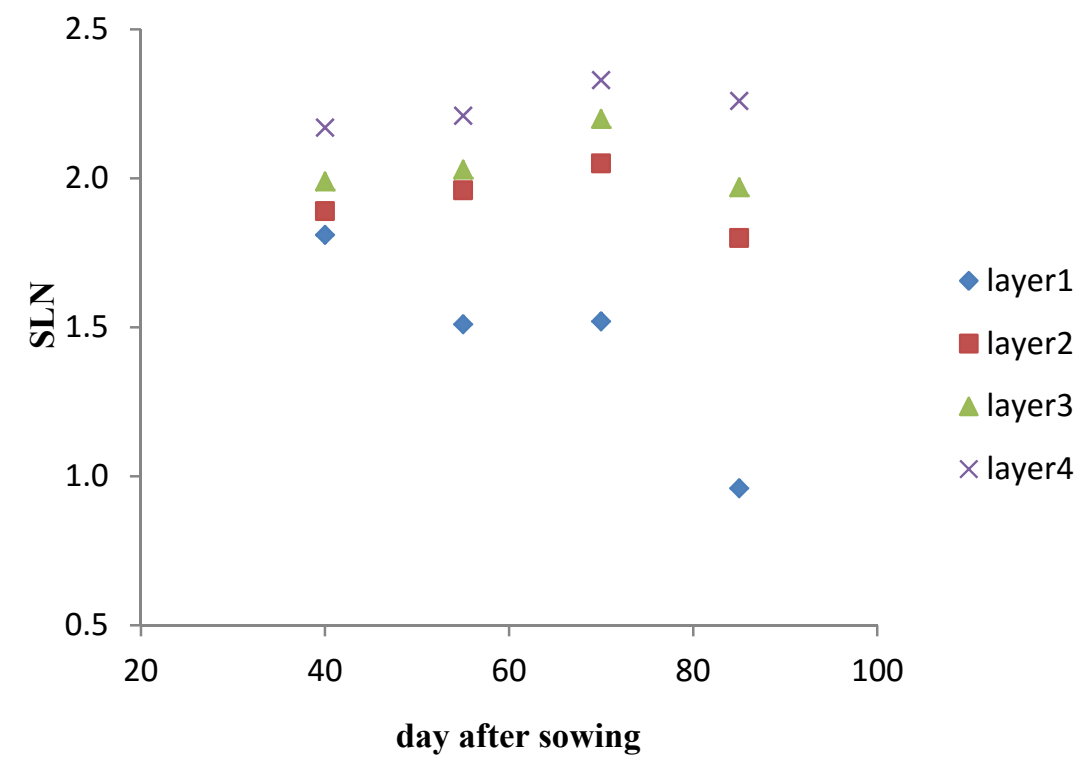

Figure 5. Dynamics of leaf $\mathrm{N}$ per unit leaf area (SLN) for the four canopy layers in $450 \mathrm{Kg} / \mathrm{ha}$ treatments

The trend of nitrogen changes in leaf surface for density treatmentsfollowed the canopy general trend (Figures 6 to 8, compared with Figure 1) so that the first layer (lower layer) during the growth of the SLN had a decline trend and other layers initially decreased and then increased.

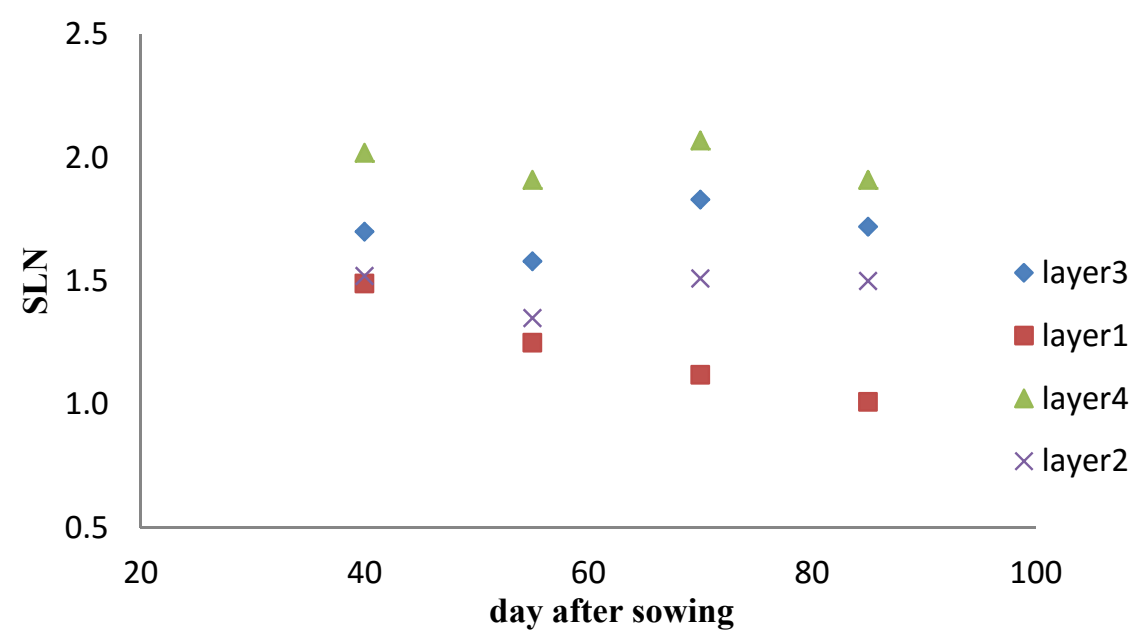

Figure 6. Dynamics of nitrogen of leaf per unit leaf area, in four canopy layers in 7 per m2 plant density

The interesting point in this trial was that while the lower layer reduced the amount of nitrogen per unit leaf area, higher layershad increases in the values. 


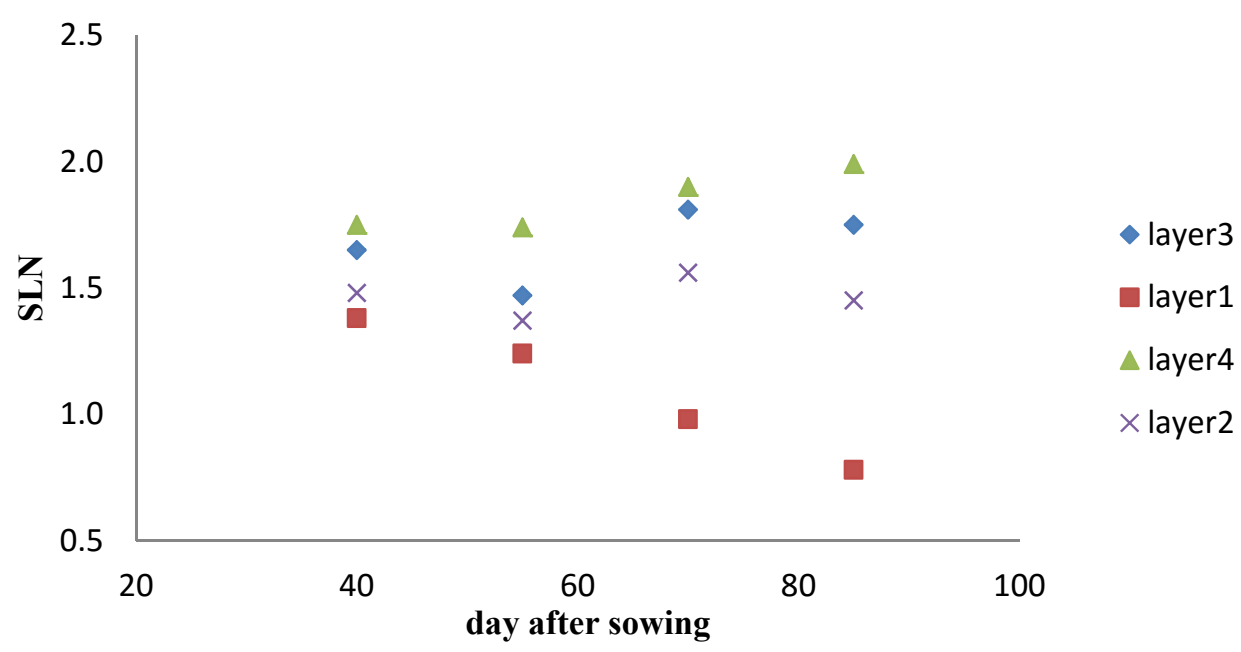

Figure 7. Dynamics of nitrogen of leaf per unit leaf area, in four canopy layers in 7.7 per $\mathrm{m}^{2}$ plant density

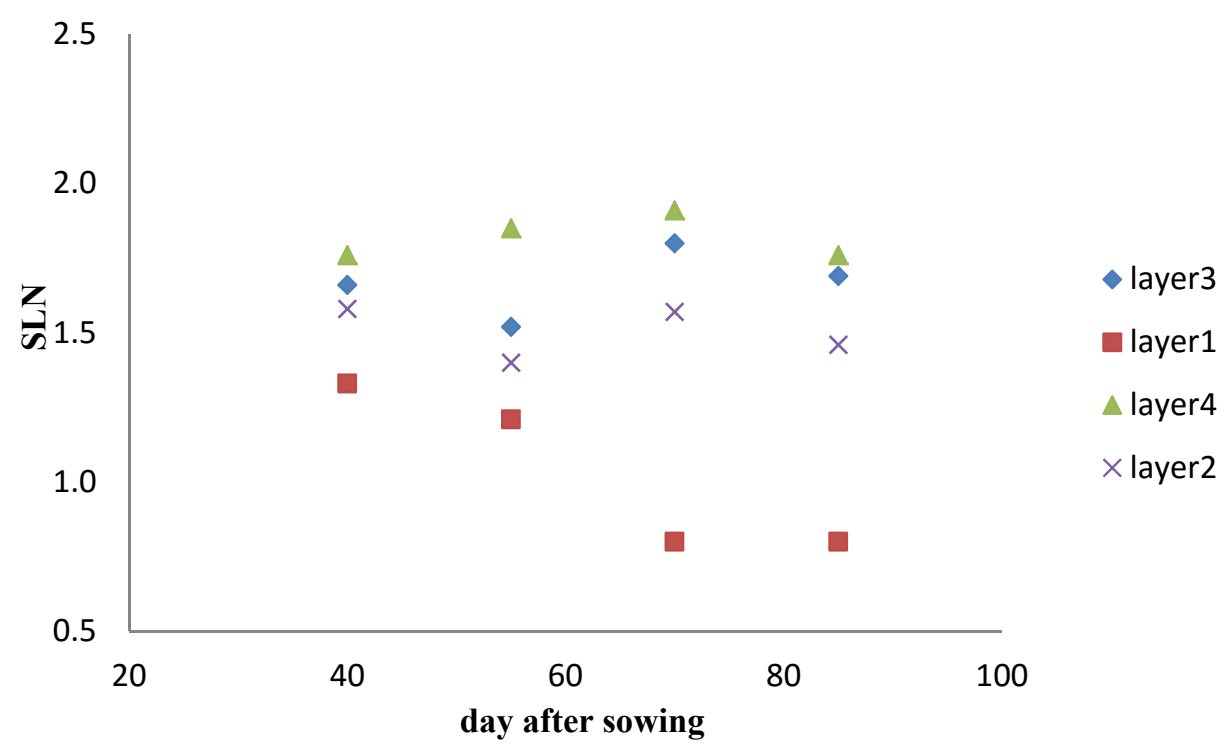

Figure 8. Dynamics of nitrogen of leaf per unit leaf area, in four canopy layers in 8.4 per m2 plantdensity

SLN gradients were consistently found over the duration of measurements (Figure 6-8). These gradients were observed over the period of measurement. In all treatments, SLN was always lower in the lower layers of the canopies (Figure 6-8). The dynamics of SLN was generally reflecting the pattern of total canopy SLN (Figure 2-3). On the other hand, the first layer (the lowest layer) declined in during growth stages, the trend was for each layer to show an initial decline followed by an increase. It seems that the reduction in the nitrogen content of leaves to support the filling of grains is certainly essential because in the final stages of development, the actual amount of the absorbed nitrogen was possible that to provide the needed nitrogen to make proteins had not sufficient seed. In this way, the reduction caused the loss of index of leaf level and leaf senescence, especially in lower leaves of the plant. This process by Sinclair and De-Witt (1975) was called as self-destruction or suicide. Different species also showed that total nitrogen in per unit of leaf in canopy different heightswere not the same and gradually decreased with increasing depth (Field, 1983; Hiros \& Werger, 1987 \& Evans, 1993).

\section{Conclusions}

A clear vertical $\mathrm{N}$ gradient was established in canopies of maize crops. SLN of a layer could be related to the plant populations and $\mathrm{N}$ supply.The vertical $\mathrm{N}$ gradient became more marked with ongoing vegetative development. The whole canopy photosynthetic benefit that would accrue from maintaining the $\mathrm{N}$ gradient is 
likely to be accentuated. The rate of decline in leaf $\mathrm{N}$ concentration in a layer was not related to either the initial concentration in the leaves within the layer.

\section{Reference}

Caloin, M., \& Yu, O. (1984). Analysis of the time course of change in nitrogen content in Dactylisglomerata L. using a model of plant growth. Ann. Bot., 54, 69-76.

Cathcart, R. J., \& Swanton, C. J. (2003). Nitrogen management will influence threshold values of green foxtail (Setariaviridis) in corn. Weed Sci., 51, 975-86.

Charles-Edwards, D. A., Stutzel, H., Ferraris, R., \& Beech, D. F. (1987). An analysis of spatial variation in the nitrogen content of leaves from different horizons within a canopy. Ann. Bot., 60, 421-426.

Ciampitti, I. A., \& Vyn, T. J. (2012). Physiological perspectives of changes over time in maize yield dependency on nitrogen uptake and associated nitrogen efficiencies: A review. Field Crops Res., 133, 48-67.

D'Andrea, K. E., Otegui, M. E., \& Cirilo, A. G. (2008). Kernel number determination differs among maize hybrids in response to nitrogen. Field Crops Research, 105, 228-239.

Drouet, J. L., \& Bonhomme, R. (1999). Do variations in local leaf irradiance explain changes to leaf nitrogen within row maize canopies. Ann. Bot., (London)84, 61-69.

Drouet, J. L., \& Bonhomme, R. (2004). Effect of 3D nitrogen, dry mass per area and local irradiance on canopy photosynthesis within leaves of contrasted heterogeneous maize crops. Ann. Bot., (London)93, 699-710.

Farnham, E. (2001). Row spacing, plant density and hybrid effects on corn grain yield and moisture. Agron. J., 93, 1049-1053.

Field, C. (1983). Allocating leaf nitrogen for the maximization of carbon gain: Leaf age as a control on the allocation program. Oecologia, 56, 341-347.

Hammer, G. L., Van Oosterom, E. J., Chapman, S. C., \& McLean, G. (2001). The economic theory of water and nitrogen dynamics and management in field crops. In A. K. Borrell , \& R. G. Henzell (Eds.), 4th Australian Sorghum Conference, 5-8 February 2001, Brisbane, Qld. CD-ROM. Queensland Government Department of Primary Industries: Toowoomba, Qld.

Hirose, T., \& Werger, M. J. A. (1987). Maximizing daily canopy photosynthesis with respect to the leaf nitrogen allocation pattern in the canopy. Oecologia, 72, 520-526.

Lemaire, G., \& Gastal, F. (2009). Quantifying crop responses to nitrogen deficiency and avenues to improve nitrogen use efficiency. In V. O. Sadras, \& D. F. Calderini (Eds.), Crop physiology: Applications for Genetic Improvement and Agronomy, (pp. 171-211). (Academic Press: San Diego, CA).

Lemaire, G., Van Oosterom, E. J., Jeuffroy, M. H., Gastal, F., \& Massignam, A. M. (2008).Crop species present different qualitative types of response toNdeficiency during their vegetative growth. Field Crops Research, $105,253-265$.

Lemaire, G., Van Oosterom, E., Sheehy, J., Jeuffroy, M. H., Massignam, A., \& Rossato L. (2007). Is crop demand more closely related to dry matter accumulation of leaf area expansion during vegetative growth? Field Crops Research, 100, 91-106.

Lemaire, G., \& Gastal, F. (1997). N uptake and distribution in plant canopies. In Diagnosis of the Nitrogen Status in Crops. Ed. Lemaire, G. pp. 3-43. Springer-Verlag, Berlin.

Lemaire, G., Khaithy, M., Onillon, B., Allirand, J. M., Chartier, M., \& Gosse, G. (1992). Dynamics of accumulation and partitioning of $\mathrm{N}$ in leaves, stems, and roots of lucerne (Medicago sativa L.) in a dense canopy. Ann. Bot., (London)70, 429-435.

Muchow, R. C., \& Sinclair, T. R. (1994). Nitrogen response of leaf photosynthesis and canopy radiation use efficiency in fieldgrown maize and sorghum. Crop Sci., 34, 721-727.

Muchow, R. C., \& Davis, R. (1988). Effect of nitrogen supply on the comparative productivity of maize and sorghum in a semiarid tropical environment. II. Radiation interception and biomass accumulation. Field Crops Research, 18, 17-30

Pons, T. L., \& Pearcy, R. W. (1994). Nitrogen reallocation and photosynthetic acclimation in response to partial shading in soybean plants. Physiol. Plant., 92, 636-644. 
Sadras, V. O., Hall, A. J., \& Connor, D. J. (1993). Light-associated nitrogen distribution profile in flowering canopies of sunflower (Helianthus annuus L.) altered during grain growth. Oecologia, 95, 488-494.

Sinclair, T. R., \& Horie, T. (1989). Leaf nitrogen, photosynthesis, and crop radiation use efficiency: A review. Crop Science, 29, 90-98.

Vos, J., Van der Putten, P. E. L., \& Birch, C. J. (2005). Effect of nitrogen supply on leaf appearance, leaf growth, leaf nitrogen economy, and photosynthetic capacity in maize (Zea mays L.). Field Crops Research, 93, 6473.

Vos, J., \& Van der Putten, P. E. L. (1998). Effect of nitrogen supply on leaf growth, leaf nitrogen economy and photosynthetic capacity in potato. Field Crops Research, 59, 63-72.

\section{Copyrights}

Copyright for this article is retained by the author(s), with first publication rights granted to the journal.

This is an open-access article distributed under the terms and conditions of the Creative Commons Attribution license (http://creativecommons.org/licenses/by/3.0/). 